\title{
The Impact of Macroeconomic Factors on Credit Risk in Conventional Banks and Islamic Banks: Evidence from Indonesia
}

\author{
Huey-Yeh Lin ${ }^{1}$, Nuraeni Hadiati Farhani ${ }^{1} \&$ Meihua $\mathrm{Koo}^{2}$ \\ ${ }^{1}$ Department of Finance, National Formosa University, Yunlin County, Taiwan \\ 2 Department of Accounting, College of Business Administration, California State Polytechnic University at Pomona, \\ USA \\ Correspondence: Huey-Yeh Lin, Department of Finance, National Formosa University, No.64, Wunhua Rd., Huwei, \\ Township, Yunlin County 632, Taiwan. Tel: 886-978-389-595.
}

\author{
Received: May 23, 2016 \\ Accepted: June 19, 2016 \\ Online Published: July 4, 2016 \\ doi:10.5430/ijfr.v7n4p105 \\ URL: http://dx.doi.org/10.5430/ijfr.v7n4p105
}

\begin{abstract}
The banking sector is viewed as an important figure in the economic development. However, this sector is vulnerable to macroeconomic instability which lead to higher credit risk of banks. Motivated by the fact that unlike conventional banking, there is limited research study about the impact of macroeconomic factors on credit risk in Islamic banking. Therefore, further research to study about it has become important. This research aim is to evaluate the association between macroeconomic factors with credit risk through comparative analysis of these two kinds of banking system. Empirical results suggest that Islamic banks are more resistant during crisis, and only two variables (Exchange Rate and MS) which are significant to credit risk in Islamic banks. Meanwhile, in conventional banks almost all variables are significant except Industrial Production Index. This research is expected to give contributions to literature, and provide comparable information on the credit risk profile across the banks to stakeholders.
\end{abstract}

Keywords: credit risk, macroeconomic factors, Islamic bank, conventional bank

\section{Introduction}

Recently, Indonesia is much more vulnerable to any economic shocks toward trade, banking, and investment. According to Tambunan (2010) Indonesia experienced two big economic crises and one small crisis (Presidential secretariat office BPS and BI, 2015). The first happened in 1997/1998 was triggered by a sudden capital flight from the country that caused Indonesia's local currency, rupiah to depreciate significantly against the US dollar. Second, in 2007 there was a financial crisis started with the subprime mortgage in the United States. The impact of the crisis has been forced around 123 banks in the US, including Lehman Brother (Gup, 2010). Begin September 2008, it spread and has affected many countries (Marshall, 2009). Then, the latest happened in September 2015 devaluation of China's Yuan caused rupiah depreciate to IDR 14.054 per US dollar (Bloomberg Dollar Index).

The macroeconomic instability during crises have the greatest impact toward banking and lead to the banking crisis. The worst impact of crisis to banking sector happened in 1998. Most of the banks at that time were considered sound got bankrupt due to adverse macroeconomic Nursechafia (2014). Therefore, it becomes a priority for the stakeholders to pay attention to keep the stability of the bank. In order to keep bank stable, it is important to manage the risk. Based on Carey (2001), risk management is the foundation of banking business because it allows the banks to offer services sustainably.

One of the performance indicators to measure the stability level is Non Performing Loan (for conventional banks) and Non Performing Financing (for Islamic banks) since Indonesia is implemented under a dual banking system conventional and Islamic bank. From the risk management point of view, it is important for stakeholders (including investors and depositors) to know whether these two kinds of banking system exhibit different levels of credit risk with principle that the basis of the conventional banking system is interest, while Islamic banks utilizing the funds on a profit and loss sharing basis.

However, despite the relevant coverage of literature about impact of macroeconomic variables on conventional banks' credit risk. There is relatively limited empirical research that has tested that impact on Islamic banking (e.g., Adebola (2011); Cihak \& Hesse (2008); Havidz \&Setiawan (2015); Al Waesabi (2013); Nursechafia (2014); Rahman \& 
Shahimi (2010). A number of papers discuss risks in Islamic banking, but in theoretical terms instead of analysis of data. Hence, this study is expected to fill this gap in the literature.

The purpose of this study is to find out whether Islamic banks and conventional banks have different level of credit risk by analyzed the association of macroeconomic indicators with credit risk in NPL and NPF using 91 conventional banks and 10 Islamic banks during the study period from 2008 to 2015.

The structure of this paper is as follows. Section 2 presents a short overview of Islamic banking, and the hypotheses that used in this study. Section 3 presents the research methodology, and introduces the variables used in the paper. Section 4 compares the results of conventional and Islamic banks. Finally, section 5 summarizes the conclusion.

\section{Literature Review}

\subsection{Overview of Islamic Banking}

Islamic banking refers to a system banking, which is based on Islamic Shariah (law) and prohibits the payment and collection of riba (interest). According to Schacht (1964) on Lewis (2001) riba is simply a special case of unjustified enrichment or, in the terms of the Holy Qur'an, consuming (that is, appropriating for one's own use) the property of others for no good reason, which is prohibited. The main argument against the interest, according to the Institut Islamic Banking \& insurance, money in Islam is not regarded as an asset from which it is ethically allowed to earn a direct return and money tends to be viewed purely as a medium of exchange. Interest can lead to injustice and oppression in society. Therefore, this concept encourages to invest the money to concrete projects and profit sharing instead of interest earned. The comparison between those two kinds of concept is presented in Table 1.

Table 1. Differences between interest and profit and loss sharing

\begin{tabular}{lll}
\hline Aspects & Interest & Profit and loss sharing \\
\hline Determination of Profit & $\begin{array}{l}\text { Predetermined of interest rate with } \\
\text { the assumption must be always } \\
\text { profitable }\end{array}$ & $\begin{array}{l}\text { Determine at the time of the contract with the } \\
\text { possibility profit or loss }\end{array}$ \\
\hline Risk ownership & $\begin{array}{l}\text { Customers bear all risk to loan (risk } \\
\text { transfer) }\end{array}$ & $\begin{array}{l}\text { The risk of loss will be borne by two parties } \\
\text { (risk sharing) between investor and } \\
\text { entrepreneur or between lender and borrower } \\
\text { (according to contract) }\end{array}$ \\
\hline $\begin{array}{l}\text { Determination of percentage } \\
\text { of returns }\end{array}$ & Based on the loan amount & $\begin{array}{l}\text { Based on the activities done to achieve some } \\
\text { profit }\end{array}$ \\
\hline Payment & $\begin{array}{l}\text { As promised without consideration } \\
\text { profit or loss }\end{array}$ & \begin{tabular}{l} 
Based on the increase of the total revenue \\
\hline
\end{tabular}
\end{tabular}

Source: Antonio (2010)

Credit risk is associated with each financial product which are provided by the banks. As a result, the nature of credit risk in Islamic banks differs markedly from conventional banks. Following are the main modes of financing from Islamic banks, according to Waseem (2014):

1. Mudaraba: a profit sharing partnership between "rabb al maal (capital provider)" and "mudarib (manager)". The profit shared among the two in a pre-agreed ratio, while the losses are borne exclusively by capital provider. The entrepreneur is covered by limited liability provisions.

2. Murabaha: a sales of goods contract which the payment include a profit margin agreed upon by the two parties. This product is predominantly offered by Islamic banks in asset financing, property, and commodity export and import.

3. Musharaka: a profit sharing partnership in the agreement to share profits with a pre-agreed ratio and share losses based on the ratio of contribution.

\subsection{Comparison between Conventional and Islamic Bank}

Indonesia is one of a country who implemented under a dual banking system in compliance with the Indonesian banking architecture. Conventional and Islamic banking system jointly and synergically supports a wider public fund 
mobilization in the framework financing capability of national economic sectors. Conventional banking is based on the principle of making profit from borrowing and lending rates of interest. Interest charged on a loan can be multiple of the principle, depending on the length of the loan period. In other words, the principle is contradictive with Islamic banking. Table 2 is presented to give an understanding about the comparison between those dual banking systems.

Table 2. Differences between conventional banks and Islamic banks

\begin{tabular}{lll}
\hline Aspects & Conventional Banks & Islamic Banks \\
\hline Principle & Based on interest transaction & $\begin{array}{l}\text { The absence of interest-based (riba) } \\
\text { transaction, but based on profit and loss } \\
\text { sharing }\end{array}$ \\
\hline Operational & $\begin{array}{l}\text { Profitable transaction. Halal is not a major } \\
\text { consideration }\end{array}$ & $\begin{array}{l}\text { Halal (legal, permitted based on Islamic rule) } \\
\text { and profit business transactions only }\end{array}$ \\
\hline $\begin{array}{l}\text { Structure } \\
\text { Organization }\end{array}$ & $\begin{array}{l}\text { Only under the supervision of Bank } \\
\text { Indonesia }\end{array}$ & $\begin{array}{l}\text { Under the supervision of Bank Indonesia, } \\
\text { National Sharia Council, and Sharia } \\
\text { supervisory Board }\end{array}$ \\
\hline Relationship & $\begin{array}{l}\text { Relationship is often defined as that of } \\
\text { creditor-debtor }\end{array}$ & $\begin{array}{l}\text { The relationship to its clients defined as } \\
\text { partners, investors and trader, buyer and } \\
\text { seller }\end{array}$ \\
\hline $\begin{array}{l}\text { Evaluation of } \\
\text { project }\end{array}$ & $\begin{array}{l}\text { Since income from the advances, it gives } \\
\text { little attention to developing expertise in } \\
\text { assessment of the project and evaluation. } \\
\text { Risks are transferable at a price (and } \\
\text { sometimes incremental) }\end{array}$ & $\begin{array}{l}\text { Since it shares profit and loss, the Islamic } \\
\text { banks pay greater attention to developing in } \\
\text { assessment of the project and evaluations }\end{array}$ \\
$\begin{array}{l}\text { Contract structure } \\
\text { of loan between } \\
\text { investor and } \\
\text { entrepreneur }\end{array}$ & $\begin{array}{l}\text { The investor / lender is guaranteed of a } \\
\text { predetermined rate of interest or returns }\end{array}$ & $\begin{array}{l}\text { It promotes risk sharing between investor and } \\
\text { the user of funds /entrepreneur }\end{array}$ \\
\hline
\end{tabular}

Source: Antonio (2010); Bakar (2010); Ahmad, A.U.F (2010)

\subsection{The Impact of Macroeconomic on Credit Risk}

The relationship between macroeconomic indicators and credit risk has been widely discussed by connecting the financial vulnerability and stability of banking sectors. This study will attempt to highlight the impact of macroeconomic factors to credit risk (NPL and NPF). Some researcher believes that macroeconomic conditions are the main source of the systematic risk that reflects on the growth of or decline of loan default Touny \& Shehab (2015). In addition, Ahmad \& Bashir (2013) explain that during depression asset price kept as collateral will decline and results in growth of NPL. In order to prevent this kind of situation, it is important for government policy makers identify the macroeconomic factors to keep the bank's stability by ratio NPL and NPF.

Empirical studies have confirmed the linkage between macroeconomic and stability of two kinds system banks. For instance, unlike conventional banking system, Islamic banking using profit and loss sharing instead of interest rate might exhibit different level of credit risk. A number of empirical studies have undertaken a comparative analysis of the credit risk of conventional and Islamic banking. Based on (Beck, Demirgüç-Kunt, \& Merrouche, 2012); Rahim \& Zakaria (2013); Ali (2013); and Ferhi (2015) conclude that Islamic banks are more stable than conventional banks. On the other hand, Elsiefy (2012) concludes that Islamic banking model implies a higher level of risk.

Crisis

A number of empirical studies have undertaken a comparative analysis of the credit risk of conventional and Islamic banking. Beck et al. (2012) investigate business orientation, efficiency, asset quality, and stability of 22 countries over 1995-2009. In asset quality aspect, the study finds that during crises, Islamic banks have significantly lower non-performing loans and loan loss provisions during crisis. This confirms previous studies Rahim \& Zakaria (2013); Ali (2013); and Ferhi (2015). On the other hand, Elsiefy (2012) who investigated banking sector in Qatar using 
sensitivity scenario test find that Islamic banks appear to be more exposed to credit risk compared to conventional banks as the impact of credit quality would have been severer on Islamic banks as compared to conventional banks. In addition, Islamic banks assume have a higher credit risk post the global crisis in 2008 compared to before the crisis. Based on this explanation, the following hypotheses are proposed:

\section{H1-1: Financial crisis has an impact on credit risk of Conventional Banks.}

\section{H1-2: Financial crisis has an impact on the credit risk of Islamic Banks.}

Industrial Production Index

Several studies in conventional banking have found that Industrial Production Index as a significant variable explaining credit risk. Ahmad \& Bashir (2013) find that the industrial production index has a negative significance effect to NPL. This confirms previous studies by Kalirai (2002); Vatansever (2013); and (Festiae, Mejra, \& Kaykler, 2011). In Islamic banking research area, the results are different among some researchers. Adebola (2011) revealed that Industrial Production Index has a positive relationship but insignificant to credit risk. However, Nursechafia (2014) who examine the same country with this current study, which is Indonesia in the period 2005 until 2012 argues that Industrial Production Index has a negative and significant relationship with credit risk. Nursechafia (2014) propose the reason for the negative relationship is the better condition of economic growth reflected an increase of Industrial Production index which leads to an increase of loan repayment capacity. As a result, credit risk in Islamic banks decreased. Thus, the above arguments lead to the following hypotheses:

\section{H2-1: Industrial Production index has a negative impact on credit risk of Conventional Banks.}

\section{H2-2: Industrial Production Index has an impact on credit risk of Islamic Banks.}

\section{Bank Indonesia Certificate Rate/ Bank Indonesia Certificate Sharia Rate (SBIR/SBISR)}

For SBIR/ SBISR, this is the proxy of interest rate. Singjergji (2013) investigates the main macroeconomic variables in the Albanian banking find that there is a positive and significant relationship between interest rate and credit risk. This confirms previous studies Farhan (2012); Ahmad \& Bashir (2013); and Bofondi (2011) indicate that interest rate affects the amount of bad debt in the case of floating interest rate. Therefore, the increase in the debt caused by the increase in payment of interest rates and result in the rise of non-performing loan. The above arguments are undertaking research in conventional banking. On the other hand, in Islamic banking research, the results show different impact. For instance, Al-Waesabi (2013) notice that interest rate do not statistically significant, but Adebola (2011) who investigate Islamic banking sector in Malaysia indicates the interest rate has a significant and positive impact with credit risk. Therefore, this argument suggests the development of the following hypotheses:

\section{H3-1: SBIR has a positive impact on credit risk of Conventional Banks.}

\section{H3-2: SBIRS has an impact on credit risk of Islamic Banks.}

\section{Inflation}

There are two empirical evidence of the relationship between inflation and credit risk in conventional banks. It can be negative or positive. According to Khemraj (2009) finds that inflation were both positive and significant in affecting non- performing loan. Similar results are reported by Farhan (2012); Fofack (2005); and Ghosh (2015). However, Ahmad \& Bashir (2013); Shingjergji (2013); Babihuga (2007); Dash \& Kabra (2010); and Touny \& Shehab (2015) find a negative relationship between inflation and credit risk. These two different results are supported by Nkusu (2011) explain that the result can be positive or negative depend on economy of operations. Higher inflation can enhance the loan payment capacity of borrower by reducing the real value of outstanding debt. Moreover, increased inflation can also weaken the loan payment capacity of the borrowers by reducing the real income when wages are sticky. For Islamic banking, Čihák \& Hesse (2008), Havidz \& Setiawan (2015) and Al-Waesabi (2013) notice that inflation does not appear to be relevant to credit risk. In other words, conventional and Islamic banks show different impact of inflation to credit risk. Thus, the above arguments lead to the following hypotheses:

\section{H4-1: Inflation has an impact on credit risk of Conventional Banks.}

\section{H4-2: Inflation has an impact on credit risk of Islamic Banks.}

\section{Exchange Rate}

The impact of exchange rate on credit risk is closely related to export and import activity and give different direction based on some literature on research area of two kinds of banking system. Most of the studies on conventional banks find that exchange rate have a significant and positive impact to credit risk (see for example: Fofack (2005); 
Shingjergji (2013); Khemraj \& Pasha (2009); Akinlo (2014)). Fofack (2005) revealed the result of positive impact is due to the large concentration of loans to the export-oriented agriculture sector, exchange rate appreciation may limit growth prospects by squeezing profit margin which lead to higher NPL. Meanwhile, in Islamic banking, Čihák \& Hesse (2008); and Nursechafia (2014) find a negative relationship between exchange rate and credit risk. Nursechafia (2014) implies that the majority of export activity in Indonesia still depend on imported tool and machinery. Thus, the depreciation value influences the import price increase, which impact to weaken the ability of the company to repay the loan. The above arguments support the view that a strong domestic currency hamper exports and make imports cheaper. Adversely, a weaker domestic currency stimulates exports and makes imports more expensive (Investopedia, 2016). Based on above discussion, the exchange rate have related to credit risk for islamic banks and the following hypotheses are proposed:

\section{H5-1: Exchange rate has a positive impact on credit risk of Conventional Banks.}

\section{H5-2: Exchange rate has an impact on credit risk of Islamic Banks.}

\section{Money Supply (MS)}

In conventional banking research area, most of the studies find a positive impact of money supply to credit risk. Akinlo (2014) revealed that the increase in aggregate stock of money may have contributed to a deterioration of the bank's portfolio in a country and leads to an increase in non-performing loans. This confirms previous studies Badar (2013); and Fofack (2005). However, Nikolaidou (2011); and Touny \& Shehab (2015) find a negative relationship because the increase in money supply will stimulate investment and consumption and consequently will increase the income and therefore increase the ability of debtors to meet their loan obligation. For Islamic Banking, Rahman \& Shahimi (2010); and Nursechafia (2014) find that money supply is positively related to credit risk. Hence, the following hypotheses are proposed:

\section{H6-1: MS has a positive impact on credit risk of Conventional Banks.}

\section{H6-2: MS has has an impact on credit risk of Islamic Banks.}

Based on the literature review that discussed above, there is relatively limited academic papers that has tested the impact of macroeconomic variables on credit risk in Islamic banking. Therefore, this study expected to contribute to the existing literature on this topic. Unlike previous research, this study conduct in Indonesia which implemented dual banking system, conventional and Islamic banking system that is operates alongside in the industry. Thus enable to explicitly compare the two banking system by analyze the impact.

\section{Methodology}

\subsection{Data Sample of Study}

The panel data has been used to conduct the empirical analysis on the determinants of credit risk of two kinds of banking system. The research sample comprised quarterly data from 91 conventional banks and 11 Islamic Banks, which are collected from the Indonesian Banking Statistics (SPI, Bank Indonesia) and Central Bureau of Statistic from 2008 until 2015.

\subsection{Model and Operational Definition of Variables}

This study uses OLS regression model to test the variables affecting credit risk. Moreover, the variables of the study are presented and explained in Table 3.

Since it employs a different case study, this study separated into two main models, namely conventional banks model which uses NPL as dependent variable, and Islamic banks model which use NPF as dependent variable.

The baseline models are formulated as follows

$$
\begin{aligned}
& \mathrm{NPL}_{\text {it }}=\beta_{0}+\beta_{1} \text { Crisisit }+\beta_{2} \mathrm{IPX}_{\mathrm{it}}+\beta_{3} \mathrm{INF}_{\mathrm{it}}+\beta_{4} \mathrm{ER}_{\mathrm{it}}+\beta_{5} \mathrm{SBIR}_{\mathrm{it}}+\beta_{6} \mathrm{MS}_{\mathrm{it}}+\varepsilon_{\mathrm{it}} \\
& \mathrm{NPF}_{\text {it }}=\beta_{0}+\beta_{1} \text { Crisisit }+\beta_{2} \mathrm{IPX}_{\text {it }}+\beta_{3} \mathrm{INF}_{\text {it }}+\beta_{4} \mathrm{ER}_{\text {it }}+\beta_{5} \mathrm{SBISR}_{\text {it }}+\beta_{6} \mathrm{MS}_{\text {it }}+\varepsilon_{\text {it }}
\end{aligned}
$$

Where,

NPLit $\quad$ : the dependent variable for first model, credit risk of Conventional Banks for bank (i) at time ( $t)$.

$\mathrm{NPF}_{\text {it }} \quad$ : the dependent variable for first model, credit risk of Islamic Banks for bank (i) at time (t).

Crisisit : Dummy variable $=1$ if there is a crisis and $=0$ otherwise

IPX $X_{i t}:$ the Industrial Production Index for bank (i) at time (t).

INF it : the inflation rate for bank (i) at time (t). 


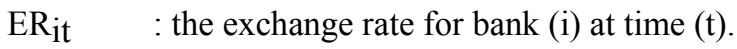

SBIR $_{\text {it }}$ : the certificate of Bank Indonesia rate for conventional banks for bank (i) at time (t).

SBISR $_{i t}$ : the certificate of Bank Indonesia rate for Islamic banks for bank (i) at time (t).

MS : the Money Supply for bank (i) at time (t).

Table 3. Definitions of the study variables

\begin{tabular}{|c|c|}
\hline $\begin{array}{l}\text { Macroeconomic } \\
\text { Variables- Independent } \\
\text { Variable }\end{array}$ & Description/ Explanation \\
\hline \multicolumn{2}{|c|}{ Dummy Variable: Crisis Equal to 1 for crisis at 2008-2009 and zero otherwise } \\
\hline $\begin{array}{l}\text { Industrial Production } \\
\text { Index }\end{array}$ & $\begin{array}{l}\text { Indicator reflects similar changes in overall economic activity (GDP). In other words, it } \\
\text { represents a country's economic growth, which measure real production output. Industrial } \\
\text { Production Index is more exhaustive compared to GDP in explaining economic growth in } \\
\text { monthly basis. It covers broad sectors, namely, mining, manufacturing, and electricity. } \\
\text { Investopedia (2016), Linda (2007) on Nursechafia (2014) }\end{array}$ \\
\hline Inflation & $\begin{array}{l}\text { Persistent, ongoing rise across a broad spectrum of prices. An increase in prices for one or } \\
\text { two goods alone cannot be described as inflation unless that increase spreads to (or leads } \\
\text { to escalating prices for) other goods (Bank Indonesia Regulation) }\end{array}$ \\
\hline Exchange Rate & Relative price of a local currency against other currencies (Rupiah to USD) \\
\hline SBIR & $\begin{array}{l}\text { Bank Indonesia Certificate Rate. SBIR is securities in the Rupiah currency issued by Bank } \\
\text { Indonesia in recognition of short-term debt using discount system. It is one of the } \\
\text { monetary policy instruments used by Bank Indonesia to conduct open market operations } \\
\text { to absorb excess liquidity in the market. SBIR is the proxy for Interest Rate for } \\
\text { Conventional Bank (Bank Indonesia Regulation) }\end{array}$ \\
\hline SBISR & $\begin{array}{l}\text { Bank Indonesia Certificate Sharia Rate. SBISR is short-term securities in the rupiah } \\
\text { currency issued by Bank Indonesia based on Sharia principles using auction mechanism } \\
\text { with contract system. It has the same purpose with SBIR, to conduct open market } \\
\text { operations to absorb excess liquidity in the market. SBISR is the proxy for interest rate for } \\
\text { Islamic Bank. (Bank Indonesia Regulation) }\end{array}$ \\
\hline MS & $\begin{array}{l}\text { Money supply or quasi money or M2. The generally accepted definition of all countries } \\
\text { does not exist, because the typical of each country need to be considered. M2 is defined as } \\
\text { M1 plus time deposits (time deposits) and savings balances (savings deposits) belongs } \\
\text { community on the banks, because the development of M2 can also be affecting the price } \\
\text { development, production and economic conditions in general. In Indonesia, M2 includes } \\
\text { all time deposits and certificate deposits at banks. Boediono (1985) }\end{array}$ \\
\hline \multicolumn{2}{|l|}{$\begin{array}{c}\text { Credit Risk- } \\
\text { Dependent Variable }\end{array}$} \\
\hline $\begin{array}{l}\text { Non Performing Loan } \\
\text { (NPL) }\end{array}$ & $\begin{array}{l}\text { Ratio between the number of total loans to loans which the collectibility are classified as } \\
\text { substandard, doubtful, and bad debt. NPL is the term for Conventional Bank (Bank } \\
\text { Indonesia Regulation) }\end{array}$ \\
\hline $\begin{array}{l}\text { Non Performing } \\
\text { Financing (NPF) }\end{array}$ & $\begin{array}{l}\text { Ratio between the number of total loans to loans which the collectibility are classified as } \\
\text { substandard, doubtful, and bad debt. NPF is the term for Islamic Bank (Bank Indonesia } \\
\text { Regulation) }\end{array}$ \\
\hline
\end{tabular}




\section{Empirical Results}

\subsection{Descriptive Statistical Analysis}

Table 4 and 5 contain the descriptive statistic of some macroeconomic indicators and credit risk during the study period 2008-2015. The study sample demonstrated that conventional and Islamic banks experienced maximum NPL and NPF $51 \%$ and $18.07 \%$ respectively. These results indicate that both of the system banking exceed the maximum limit for credit risk. Based on Bank Indonesia regulation the banks should maintain the NPL and NPF at $5 \%$. However, the mean of NPL and NPF are currently safe at $2.67 \%$ and 3.24\% respectively. Furthermore, Table 6 and 7 show correlation matrix of explanatory variables of conventional and Islamic banks. Some variables show significant correlations.

Table 4. Descriptive statistics of the variables conventional banks

\begin{tabular}{lcccccc}
\hline \multicolumn{1}{c}{ Descriptive Statistics } & $\mathrm{N}$ & $\begin{array}{c}\text { Standard } \\
\text { deviation }\end{array}$ & $\begin{array}{c}\text { Minimum } \\
\text { value }\end{array}$ & $\begin{array}{c}\text { Maximum } \\
\text { value }\end{array}$ & Mean & Median \\
\hline Crisis & 2821 & 0.296 & 0 & 1 & 0.1 & 0 \\
\hline NPL & 2821 & 3.65 & 0.00 & 51.00 & 2.67 & 1.91 \\
\hline Industrial Production Index & 2821 & 3.30 & -8.70 & 8.76 & 1.10 & .99 \\
\hline SBIR & 2821 & 0.016 & 0.038 & 0.112 & 0.068 & 0.067 \\
\hline Inflation & 2821 & 2.36 & 2.78 & 12.14 & 6.27 & 5.90 \\
\hline Exchange Rate (for USD) & 2821 & 1553 & 8564 & 14396 & 10365 & 9645 \\
\hline MS (in millions Rp) & 2821 & 199225 & 409768 & 1063038 & 703156 & 714258 \\
\hline
\end{tabular}

Table 5. Descriptive statistics of the variables Islamic banks

\begin{tabular}{lcccccc}
\hline \multicolumn{1}{c}{ Descriptive Statistics } & $\mathrm{N}$ & $\begin{array}{c}\text { Standard } \\
\text { deviation }\end{array}$ & $\begin{array}{c}\text { Minimum } \\
\text { value }\end{array}$ & $\begin{array}{c}\text { Maximum } \\
\text { value }\end{array}$ & Mean & Median \\
\hline Crisis & 280 & 0.233 & 0 & 1 & 0.06 & 0 \\
\hline NPF & 280 & 2.18 & 0.01 & 18.07 & 3.24 & 2.98 \\
\hline Industrial Production Index & 280 & 3.37 & -8.70 & 8.76 & 1.42 & 1.11 \\
\hline SBISR & 280 & 0.016 & 0.038 & 0.112 & 0.068 & 0.067 \\
\hline Inflation & 280 & 1.99 & 2.78 & 12.14 & 6.02 & 5.90 \\
\hline Exchange Rate (for USD) & 280 & 1631 & 8564 & 14396 & 10490 & 9709 \\
\hline MS (in millions Rp) & 280 & 189842 & 409768 & 1063038 & 747595 & 795518 \\
\hline
\end{tabular}

Table 6. Correlation matrix of explanatory variables in conventional banks

\begin{tabular}{lcccccc}
\hline & Crisis & $\begin{array}{c}\text { Industrial } \\
\text { Production } \\
\text { Index }\end{array}$ & SBI & Inflation & Exchange Rate & MS \\
\hline Crisis & 1 & $-.354^{* *}$ & $.293^{* *}$ & $.171^{* *}$ & -0.012 & $-.342^{* *}$ \\
\hline $\begin{array}{l}\text { Industrial Production } \\
\text { Index }\end{array}$ & $-.247^{* *}$ & 1 & $-.060^{* *}$ & $-.050^{* *}$ & $.153^{* *}$ & $.328^{* *}$ \\
\hline SBI & $.527^{* *}$ & $-.132^{* *}$ & 1 & $.698^{* *}$ & $.284^{* *}$ & $-.238^{* *}$ \\
\hline Inflation & $.331^{* *}$ & $-.113^{* *}$ & $.758^{* *}$ & 1 & $.314^{* *}$ & $.054^{* *}$ \\
\hline
\end{tabular}




\begin{tabular}{llllllc}
\hline Exchange Rate & $-.058^{* *}$ & $.199^{* *}$ & $.232^{* *}$ & $.290^{* *}$ & 1 & $.576^{* *}$ \\
\hline MS & $-.372^{* *}$ & $.283^{* *}$ & $-.468^{* *}$ & $-.102^{* *}$ & $.581^{* *}$ & 1 \\
\hline
\end{tabular}

$* \mathrm{p}<0.05 \quad * * \mathrm{p}<0.01$

Spearman (Pearson) correlation coefficients are above (below) the diagonal of table

Table 7. Correlation matrix of explanatory variables in Islamic banks

\begin{tabular}{lcccccc}
\hline & Crisis & $\begin{array}{c}\text { Industrial } \\
\text { Production } \\
\text { Index }\end{array}$ & SBI & Inflation & Exchange Rate & MS \\
\hline Crisis & 1 & $-.247^{* *}$ & $.221^{* *}$ & 0.077 & -0.003 & $-.274^{* *}$ \\
\hline $\begin{array}{l}\text { Industrial Production } \\
\text { Index }\end{array}$ & $-.173^{* *}$ & 1 & 0.061 & -0.009 & $.167^{* *}$ & $.261^{* *}$ \\
\hline SBI & $.421^{* *}$ & -0.022 & 1 & $.643^{* *}$ & $.390^{* *}$ & 0.117 \\
\hline Inflation & $.217^{* *}$ & -0.078 & $.685^{* *}$ & 1 & $.431^{* *}$ & $.307^{* *}$ \\
\hline Exchange Rate & -0.016 & $.200^{* *}$ & $.372^{* *}$ & $.420^{* *}$ & 1 & $.735^{* *}$ \\
\hline MS & $-.315^{* *}$ & $.224^{* *}$ & $-.228^{* *}$ & 0.111 & $.654^{* *}$ & 1 \\
\hline
\end{tabular}

$* \mathrm{p}<0.05 \quad * * \mathrm{p}<0.01$

Spearman (Pearson) correlation coefficients are above (below) the diagonal of table

\subsection{Regression Analysis}

According to the data analysis of the Ordinary Least Square estimation the results are presented below

Table 8. Regression results of conventional banks

\begin{tabular}{|c|c|c|c|c|}
\hline $\begin{array}{c}\text { Independent } \\
\text { Variables }\end{array}$ & Coefficient & T-test & $P$ values & VIF \\
\hline Intercept & 4.156 & 0.876 & 0.381 & \\
\hline Crisis & 0.591 & 2.101 & $0.036^{* *}$ & 1.526 \\
\hline IPX & -0.014 & -0.649 & 0.517 & 1.153 \\
\hline SBIR & 29.425 & 2.476 & $0.013 * *$ & 7.561 \\
\hline INF & -0.163 & -3.126 & $0.002 * * *$ & 3.353 \\
\hline$\overline{E R}$ & 5.005 & 2.496 & $0.013^{* *}$ & 3.404 \\
\hline MS & -3.870 & -3.283 & $0.001^{* * *}$ & 4.963 \\
\hline $\mathrm{R}^{2}$ & 0.042 & & & \\
\hline F value & 20.748 & & & \\
\hline $\mathrm{P}$ value & $\mathrm{P}=0.000^{* * *}$ & & & \\
\hline
\end{tabular}

Crisis is measured by a dummy equal to 1 for crisis at 2008-2009 and zero otherwise

IPX: Industrial Production Index; SBIR: Interest Rate; INF: Inflation; ER: Exchange Rate; MS: Money Supply Variance Inflation factors (VIF's) have computed. None of the VIF's are greater than 10. This suggests that there is no multicollinearity problem (Gujarati, 2004) 
Table 9. Regression results of Islamic banks $\mathrm{NPF}_{i t}=\beta_{0}+\beta_{1}$ Crisisit $+\beta_{2} \mathrm{IPX}_{\mathrm{it}}+\beta_{3} \mathrm{SBISR}_{\mathrm{it}}+\beta_{4} \mathrm{INF}_{\mathrm{it}}+\beta_{5} \mathrm{ER}_{\mathrm{it}}+\beta_{6} \mathrm{MS}_{\mathrm{it}}+\varepsilon_{\mathrm{it}}(2)$

\begin{tabular}{lllll}
\hline \multicolumn{1}{c}{$\begin{array}{c}\text { Independent } \\
\text { Variables }\end{array}$} & Coefficient & T-test & P values & VIF \\
\hline Intercept & -35.861 & -4.145 & $0.000^{* * *}$ & \\
\hline Crisis & -0.700 & -1.147 & 0.252 & 1.321 \\
\hline IPX & -0.005 & -0.140 & 0.889 & 3.117 \\
\hline SBISR & 17.222 & 0.884 & 0.377 & 2.312 \\
\hline INF & -0.124 & -1.311 & 0.191 & 3.567 \\
\hline ER & 14.851 & 4.128 & $0.000^{* * *}$ & 3.649 \\
\hline MS & -3.559 & -1.786 & $0.075^{*}$ & \\
\hline $\mathrm{R}^{2}$ & 0.126 & & & \\
\hline F value & 6.554 & & & \\
\hline $\mathrm{P}$ value & $\mathrm{P}=0.000^{* * *}$ & & \\
\hline $\mathrm{P}<0.1 ; * * \mathrm{P}<0.05 ;$ & $* * * \mathrm{P}<0.01$ & & & \\
\hline
\end{tabular}

Crisis is measured by a dummy equal to 1 for crisis at 2008-2009 and zero otherwise

IPX: Industrial Production Index; SBIR: Interest Rate; INF: Inflation; ER: Exchange Rate; MS: Money Supply

Variance Inflation factors (VIF's) have computed. None of the VIF's are greater than 10. This suggests that there is no multicollinearity problem (Gujarati, 2004)

According to Table 8 and 9, Crisis shows different impact on the credit risk of these two kinds of banking system. In conventional banks, the relationship is positive and significant with the coefficient 0.591 . In Islamic banks the coefficient is equal to 0.70 but no impact to credit risk. The results confirm hypotheses of H1-1 which in line with similar studies by Beck et al. (2012); Rahim \& Zakaria (2013); Ali (2013); and Ferhi (2015) who have studied that Islamic banks are more resistant during crisis compared to conventional banks but rejected the hypothesis of H1-2. This may attributed to the principal and characteristic of financing in Islamic banks. The principal of PLS (profit and loss sharing) can help Islamic banks improve collectability efficiency because the allocation of funds depends on project's productivity instead of repaying the loan amount together with interest at the predetermined rate. As a result, customers of Islamic banks do not have to be worried to the change of interest rate. Moreover, the characteristic of financing of Islamic banks using the sharing of risk system. The risk of loss will be borne not only by one party, but also two parties (between investor and entrepreneur) according to the contract. Therefore, it can be considered as a main contribution for Islamic banks to be more resistant to the crisis than interest-based banks.

As expected Industrial Production Index with credit risk in both of two banking system show negative impact, but insignificant. The results reject hypotheses of H2-1 and H2-2. Industrial Production Index is not good enough to explain the impact because this index only reflects the output indicator of manufacturing sector, and the fact is the portion of giving credit for manufacturing sector is relatively small. Therefore, Industrial Production Index shows insignificant impact to credit risk.

SBIR is the proxy of the Interest Rate. Based on the result, SBIR has a positive and significant impact with the credit risk for conventional banks. These findings support hypothesis of H3-1 which equivalent to the findings of Singjergji (2013); Farhan (2012); Adebola (2011); and Ahmad \&Bashir (2013). The theoretical justification for positive association is that the increase in SBIR will be followed by the increase in bank lending rates (Bank Indonesia, 2013). It means that the borrower's capability to pay the loan become weak and result in higher credit risk because in conventional bank, the lender is guaranteed of a predetermined rate of interest or return can lead to little attention in appraisal and evaluations of project. On the other hand, in Islamic bank SBISR show insignificant impact to credit risk due to the principal of Islamic banks in using the PLS system instead of interest, but this finding does not support hypothesis of H3-2. The theoretical justification for the insignificance is that the scheme of financing contract is different with conventional banking, for instance, the risk will be borne by two parties between a provider 
of capital (investor) and the use of funds (entrepreneur). Due to the risk sharing, the two parties will pay greater attention to developing project appraisal and evaluations instead of based on interest rate. This result is equivalent to finding Al- Waesabi (2013) who reveals that the interest rate is insignificant on credit risk in Islamic Banks.

The inflation is negative and significant at the $1 \%$ level with credit risk for conventional bank which support hypothesis of H4-1. This may indicate that inflation not always give bad impact to stability of banks. Inflation during a short period of time will not reduce people's desire to fill their needs, then it means economic activity increase, then businessman can make profit. Therefore, increase the borrower's capability to pay the loan (Touny \& Shehab, 2015). Similar results are reported by Ahmad \& Bashir (2013); Shingjergji (2013); Babihuga (2007); Dash and Kabra (2010). In Islamic banks show that inflation is insignificant which reject hypothesis of H4-2. This may attributed to the fact that one of the financing in Islamic banking, for example, in murabaha financing (trade financing), the customer pays the original price plus a profit margin agreed upon by the two parties and the payment is fixed from the beginning to the end. Moreover, in partnership financing (mudharaba, musharaka) the profit is shared according to a pre- agreed ratio. Thus, inflation does not change the value of payment that customers have to be paid to the banks. As a result, when there is an increase of inflation, will not effect on the amount of payment.

For Exchange Rate, conventional banks and Islamic banks show a positive and significant to credit risk which give greater impact to Islamic banks with coefficient 14.851. These results can be attributed to the appreciation of exchange rate give bad impact in weakened the ability to repay the loan especially those entrepreneurs who depend on export activity. The result support hypothesis of H5-1 for conventional bank, and consistent with the finding of Fofack (2005); Shingjergji (2013); Khemraj and Pasha (2009); Akinlo (2014). In Islamic banks the finding also support the hypothesis of H5-2. It is interesting that although the literature Nurschefia (2014) examine Islamic banks the same country with this study, but the sign of its impact is different. This may attributed to some reasons, first the sample period of the literature does not include the year period of 2013-2015 which actually at the period of 2015, the value of export is comparatively higher than import (Central Bureau of Statistic, 2016). Therefore, the increasing value of export and appreciation of the exchange rate may lead to higher credit risk. Furthermore, time series in the form of monthly data may show different result with this study which using panel data.

Money Supply has a negative and significant impact with credit risk in conventional banks at the $1 \%$ level which is against hypothesis of H6-1. This means that when there is a high expansion in money supply will give good impact to credit risk. This finding is in line with similar studies Nikolaidou (2011); and Touny \& Shehab (2015) suggest that money supply increase productivity and stimulates investment and consumption activity. Consequently, the income will increase and the ability to pay the loan will enhance. Furthermore, Islamic banks also show a negative and significant impact at the $10 \%$ level, but the result support the hypothesis of H6-2.

Table 10. Results of study hypothesis

Conventional Banks

\begin{tabular}{ll}
\hline H1-1 Financial crisis has an impact on credit risk of Conventional Banks & Accepted \\
\hline H2-1: Industrial Production index has a negative impact on credit risk of Conventional Banks. & Rejected \\
\hline H3-1: SBIR has a positive impact on credit risk of Conventional Banks. & Accepted \\
\hline H4-1: Inflation has an impact on credit risk of Conventional Banks. & Accepted \\
\hline H5-1: Exchange rate has a positive impact on credit risk of Conventional Banks. & Accepted \\
\hline H6-1: MS has a positive impact on credit risk of Conventional Banks. & Rejected \\
\hline Islamic Banks & \\
\hline H1-2: Financial crisis has an impact on the credit risk of Islamic Banks. & Rejected \\
\hline H2-2: Industrial Production Index has an impact on credit risk of Islamic Banks. & Rejected \\
\hline H3-2: SBIRS has an impact on credit risk of Islamic Banks & Rejected \\
\hline H4-2: Inflation has an impact on credit risk of Islamic Banks. & Rejected \\
\hline H5-2: Exchange rate has an impact on credit risk of Islamic Banks. & Accepted \\
\hline H6-2: MS has an impact on credit risk of Islamic Banks. & Accepted \\
\hline
\end{tabular}




\section{Conclusion}

This study investigated the impact of macroeconomic factors on the credit risk of conventional banks and Islamic banks over 2008-2015. The study finds that Islamic banks are more resistant during crisis, and only two variables (Exchange Rate and MS) which are significant to credit risk in Islamic banks. Exchange Rate gives greater impact to Islamic banks than conventional banks. In addition, Money Supply has a negative and significant impact on credit risk at the $10 \%$ level. In conventional banks almost all variables are significant except Industrial Production Index (IPX). The finding of this study may serve as a reference for government policy makers to pay attention to bank' specific variables in Islamic bank to keep the stability of NPF since mostly of macroeconomic variables do not give significant impact. In addition, from the risk management point of view, it is important for stakeholders (including investors and depositors) a knowledge about different levels of credit risk in two kinds of banking system.

This study has limitation that despite the relevant coverage of literature about the impact of macroeconomic variables on conventional banks' credit risk. There is relatively limited empirical research that has tested that impact on Islamic banking. Moreover, further research is proposed to investigate the two factors, not only macroeconomic but also bank' specific variables in order to analyze deeply in determining of credit risk.

\section{References}

Adebola, S.S., \& Yosoff, W.S.B. (2011). An ARDL approach to the determinants of non-performing loans in islamic banking system in Malaysia. Kuwait Chapter of Arabian Journal of Business and Management Review, 1(2).

Ahmad, A.U.F. (2010). Development in Islamic Banking Practice. The Experience of Bangladesh. United States, US: Universal Publisher Boca Raton, Florida

Ahmad, F., \& Bashir, T. (2013). Explanatory power of macroeconomic as determinants of non-performing loans: Evidence from Pakistan. World Applied Sciences Journal, 22(2), 243-255. http://dx.doi.org/10.5829/idosi.wasj.2013.22.02.1863

Akinlo, O., \& Awolowo, O (2014). Determinants of non-performing loans in Nigeria. Paper presented at The Institute for Business and Finance Research, Spain.

Ali, A., \& Ghauri, S.P. (2013). Global crisis and credit risk management by banks: comparative study of banks in Pakistan. International Journal of Business and Economics Research. http://dx.doi.org/10.11648/j.ijber.20130206.15

Al-Wesabi, H.A., \& Ahmad, N.H. (2013). Credit risk of Islamic banks in GCC countries. International Journal of Banking and Finance.

Antonio, M.S. (2010). Bank Syariah dari Teori ke Praktik. Jakarta: Gema Insani.

Badar, M., \& Javid, A.Y. (2013). The impact of economic forces on non-performing loans an empirical study of commercial banks in Pakistan. Elixir International Journal Marketing Management, 56A, 13807-13814.

Bakar, A.M. (2010). Broad Distinction between Islamic Banks and Conventional Banks. Retrieved March 20, 2016, from http://www.bankislam.com

Beck, R., \& Jakubik, P. (2013). Non-performing loans what the matters in addition to the economic cycle. European Central Bank Working Paper Series, No. 1515.

Beck, T., Demirgüç-Kunt, A., Merrouche, O. (2012). Islamic vs conventional banking: business model, efficiency and stability. Journal of Banking \& Finance, 37(2013), 433-447.

Boediono. (1985). Ekonomi Makro. Yogyakarta: BPFE-UGM.

Bofondi, Marcello, \& Ropele, Tiziano. (2011). Macroeconomic Determinants of Bad Loan Evidence from Italian Banks. Occasional Papers, 89.

Carey, A. (2001). Effective risk management in financial institutions: the turnbull approach, balance sheet. The Journal of Risk Finance, 9(3), 24-27.

Čihák, M., \& Hesse, H. (2008). Islamic banks and financial stability: An empirical analysis. IMF Working Paper. $\mathrm{WP} / 08 / 16$.

Claessens, S., \& Kose, M. A. (2013). Financial Crises: Explanations, Types, and Implications. IMF Working Paper. $\mathrm{WP} / 13 / 28$.

Elsiefy, E. (2012). Stress test for Islamic and conventional banks using sensitivity scenario test: Evidence from Qatari Banking Sector. International Journal of Economics and Management Science, 1(12), 44-63.

Farhan, M., \& Sattar, A. (2012). Economic determinants of non-performing loans: perception of Pakistani bankers. European Journal of Business and Management, 4(19), 2222-2839. 
Ferhi, A., \& Chkoundali, R. (2015). Credit risk and efficiency: Comparative study between Islamic and conventional banks during the current crises. Journal of Behavioural Economics, Finance, Entrepreneurship, Accounting and Transport, 3(1)-47-56. http://dx.doi.org/10.12691/jbe-3-1-6

Festiae, Mejra, Kavkler. (2011). the macroeconomic sources of systemic risk in the banking sectors of five new EU member states. Journal of Banking and Finance, 35, 310-322.

Fofack, H. (2005). Non-performing loans in sub-Saharan Africa: Causal analysis and macroeconomic implications. World Bank Policy Research Working Paper No. 3769.

Fraser, D.R., Gup, B.E., \& Kolari, J.W. (2001). Commercial Banking- The Management Risk. South-Western College Publishing, Thomson Learning.

Ghosh, A. (2015). Banking-Industry specific and regional economic determinants of non-performing loans: Evidence from US states. Journal of Financial Stability.

Gujarati, N. D. (2004). Basic Econometrics (Fourth ed.). New York, NY: Mc Graw-Hill, Inc.

Gup, E. B. (2010). The financial and economic crisis an international perspective. USA: Edward Elgard Publishing Limited.

Havidz, S.A.H., \& Setiawan, C. (2015). Bank Efficiency and Non-Performing Financing (NPF) In the Indonesian Islamic Banks. Asian Journal of Economic Modelling, 3(3), 61-79.

Indonesia Investments. (2015, August 12). Devaluation China's Yuan Impacts on Indonesian Stocks \& Rupiah. Retrieved February 2, 2016, from http://www.indonesia-investments.com

Institute of Islamic Banking and Insurance. Prohibition of Interest. Retrieved March 15, 2016, from http://www.islamic-banking.com/prohibition_of_interest.aspx

Investopedia. Interesting Facts about Imports and Exports. Retrieved March 20, 2016, from http://www.investopedia.com/articles/investing/100813/interesting-facts-about-imports-and-exports.asp

Kalirai, H., \& Scheicher, M. (2002). Macroeconomic stress testing: preliminary evidence for Austria. OeNB. Financial Stability Report, 3, 58-74

Khemraj, T., \& Pasha, S. (2009). The determinants of non-performing loans: an econometric case study of Guyana. Paper presented at the Caribean Center for Banking and Finance BI-annual Conference on Banking and Finance, St. Augustine, Trinidad.

Lewis, K. M., \& Algaoud L. M. (2001). Islamic Banking. United Kingdom, UK: Edward Elgard Publishing Limited.

Marshall, J. (2009). The financial crisis in the US: key events, causes and responses. House of Commons Library, $09 / 34$.

Nkusu, M. (2011). Non-performing loans and macrofinancial vulnerabilities in advanced economies. IMF (International Monetary Fund) Working Paper 11/161.

Nursechafia, \& Abduh, M. (2014). The susceptibility of Islamic banks' credit risk toward macroeconomic variables. Journal of Islamic Finance, 3(1), 023-037.

Rahim, S.R.M., \& Zakaria, R.H. (2013). Comparison on stability between Islamic and conventional banks in Malaysia. Journal of Islamic Economics, Banking and Finance, 9(3).

Rahman, A.A., \& Shahimi, S. (2010). Credit Risk and Financing Structure of Malaysian Islamic Banks. Journal of Economic Cooperation and Development, 31(3), 83-105.

Shingjergji, A. (2013). The impact of macroeconomic variables on the non-performing loans in the Albanian banking system during 2005-2012. Academic Journal of Interdisciplinary Studies, 2(9), 2281-3993.

Tambunan, Tulus T.H. (2010). The Indonesia experience with two Big Economic crisis. Modern Economy Scientific Research, 1, 156-167.

Touny, M.A., \& Shehab, M.A. (2015). Macroeconomic determinants of non-performing loans: An empirical study of some Arab countries. American Journal of Economic and Business Administration, 7(1), 11-22.

Vatansever, M., \& Hepsen, A. (2013). Determining impacts on non-performing loan ratio in Turkey. Journal of Finance and Investment Analysis, 2(4), 119-129

Waseem, M. (2014). Islamic Banking Products. Retrieved March 15, 2016, from $\mathrm{http} / /$ islamicbanking.info/category/islamic-banking-products/ 